Jurnal Pemikiran \& Penelitian Psikologi

\title{
PSIKOLOGIA
}

p-ISSN: $185-0327$

e-ISSN: $2549-2136$

www.jurnal.usu.ac.id/psikologia

\section{PENGARUH SEMANGAT KERJA TERHADAP EMPLOYEE ENGAGEMENT PADA PT. PERKEBUNAN X}

\section{EFFECT OF MORALE ON EMPLOYEE ENGAGEMENT AT PT. PERKEBUNAN $X$}

\author{
Farhah Meuthia, Cherly Kemala Ulfa \\ Psikologia: Jurnal Pemikiran \& Penelitian Psikologi \\ Tahun 2017, Vol. 12, No. 3, hal.134-152
}

Artikel ini dapat diakses dan diunduh pada:

www.jurnal.usu.ac.id/psikologia

\section{Dipublikasikan oleh:}

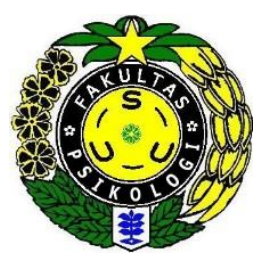

Fakultas Psikologi

Universitas Sumatera Utara

Jl. Dr. Mansyur No. 7 Medan. Telp/fax: 061-8220122

Email: psikologia@usu.ac.id 


\title{
PENGARUH SEMANGAT KERJA TERHADAP EMPLOYEE ENGAGEMENT PADA PT. PERKEBUNAN X
}

\author{
Farhah Meuthia, Cherly Kemala Ulfa \\ Universitas Sumatera Utara
}

\begin{abstract}
ABSTRAK
Penelitian ini menggunakan metode kuantitatif yang bersifat korelasional yang bertujuan untuk mengetahui seberapa besar pengaruh semangat kerja terhadap employee engagement. Subjek pada penelitian ini adalah karyawan PT. Perkebunan X yang berjumlah 42 orang. Alat ukur yang digunakan dalam penelitian ini adalah skala yaitu skala employee engagement dan skala semangat kerja yang disusun berdasarkan dimensi employee engagement oleh Menurut Macey, Schneider, Barbera \& Young (2009) serta aspek semangat kerja oleh Anoraga dan Suyati (1995). Hasil analisa data penelitian dengan menggunakan analisa regresi sederhana menunjukkan hubungan yang positif antara semangat kerja dengan employee engagement $(\mathrm{R}=0.661 \mathrm{dan} \mathrm{p}=0.000)$. Sumbangan efektif variabel semangat kerja sebesar $43.7 \%$ terhadap employee engagement. Hasil penelitian ini selanjutnya menjadi dasar untuk menetapkan intervensi berupa pelatihan peningkatan semangat kerja dengan tujuan untuk meningkatkan semangat kerja yang akhirnya akan meningkatkan employee engagement pada karyawan.
\end{abstract}

Kata kunci: Employee engagement, semangat kerja

\section{EFFECT OF MORALE ON EMPLOYEE ENGAGEMENT AT PT. PERKEBUNAN $X$}

\begin{abstract}
S
This study used quantitative correlation methods to determine the influence of the morale to employee engagement. The subject in this study were 42 employee of PT. Perkebunan X. Measurement tool used in this study was scale, namely employee engagement scale and morale scale that composed based on the dimensions of employee engagement by Macey, Schneider, Barbera \& Young (2009) and the aspect of morale by Anoraga and Suyati (1995). Data Analyze using simple regression method showed a positive relationship between morale and employee engagement. $(\mathrm{R}=0.661$ dan $\mathrm{p}=0.000)$. Contribution of morale to employee engagament was $43.7 \%$. Result of this study as basis to create an intervention in form of training that namely Improved Morale Training in order to increasing employee engagement through employee morale.
\end{abstract}

Keywords: employee engagement, employee morale

*Korespondensi mengenai penelitian ini dapat dilayangkan kepada: Psikologia@usu.ac.id
Rekomendasi mensitasi:

Farhah Meuthia \& Cherly Kemala Ulfa. (2017).

Pengaruh Semangat Kerja terhadap Employee

Engagement pada PT. Perkebunan X. Psikologia:

Jurnal Pemikiran dan Penelitian Psikologi, 12(1), 134-

152. 
PT. Perkebunan $\mathrm{X}$ adalah perusahaan swasta nasional yang bergerak dalam bidang perkebunan kelapa sawit yang didirikan pada tahun 1983. Perusahaan ini mengelola perkebunan kelapa sawitnya dengan memakai sistem swakelola yang artinya perkebunan diawasi oleh perusahaan sendiri, mulai dari penyediaan bibit, pupuk, pemeliharaan dan penjualan. Perusahaan ini memiliki lebih dari 2.351 karyawan yang terdiri dari karyawan organik 590 orang, karyawan harian tetap 327 orang, karyawan harian lepas 1.375 orang serta karyawan honorer 59 orang. Kantor pusat PT. Perkebunan X berlokasi di kota Medan, dengan jumlah karyawan sebanyak 51 orang.

Perjalanan menuju perusahaan yang lebih global tentunya membutuhkan daya upaya yang luar biasa. Fasilitas hari demi hari terus dilengkapi, dikembangkan dengan mengikuti perkembangan zaman dan teknologi. Dilain pihak ketiadaan HRD yang profesional menjadi kendala dalam menciptakan sistem manajemen yang baik bagi sumber daya manusia yang ada. Meskipun memiliki keterbatasan, departemen personalia berusaha untuk memperbaiki sistem manajemen karyawan perusahaan PT. Perkebunan X. Namun tidak dapat dipungkiri dalam pelaksanaannya banyak tantangan dan hambatan yang terjadi sehingga belum semua aspek yang ada dapat berjalan sebagaimana yang diharapkan untuk kemajuan perusahaan. Salah satu tanda rendahnya semangat kerja ditunjukkan dengan perilaku keterlambatan karyawan. Tabel hasil keterlambatan karyawan dapat dilihat sbb:

Tabel 1. Data Keterlambatan Karyawan
(Sumber: absensi PT. Perkebunan X, data diolah)

\begin{tabular}{ll}
\hline \multicolumn{1}{c}{ Bulan } & \multicolumn{1}{c}{ Terlambat } \\
\hline April & $4.6 \%$ \\
Mei & $12 \%$ \\
Juni & $15.6 \%$ \\
\hline
\end{tabular}

Dari tabel dapat dilihat bahwa pada bulan Juni, tingkat keterlambatan karyawan mencapai $15,6 \%$, bahkan 3 orang diantaranya telah mendapat surat peringatan (Data Surat Keluar Perusahaan, Juli 2012). Disamping itu, terdapat penurunan kategori baik dari hasil penilaian kinerja karyawan, data penilaian prestasi kerja karyawan dapat dilihat dalam tabel berikut:

Tabel 2. Data Keterlambatan Karyawan

(Sumber: PT. Perkebunan X, data diolah)

\begin{tabular}{ccccc}
\hline \multirow{2}{*}{ Tahun } & \multicolumn{3}{c}{ Kategori Penilaian } & $\begin{array}{c}\text { Jumlah } \\
\text { Karyawan }\end{array}$ \\
\cline { 2 - 4 } Baik & Cukup & Kurang & \\
\hline 2009 & 26 & 16 & $2(5 \%)$ & 44 \\
& $(59 \%)$ & $(36 \%)$ & & \\
2010 & 25 & 14 & 8 & 47 \\
& $(53 \%)$ & $(305)$ & $(17 \%)$ & \\
2011 & 21 & 21 & 9 & 51 \\
& $(41 \%)$ & $(41 \%)$ & $(18 \%)$ & \\
\hline
\end{tabular}

Berdasarkan tabel dapat dilihat persentase kategori baik dari penilaian kinerja karyawan untuk tahun 2011 lebih rendah dari tahun-tahun sebelumnya dan terjadi peningkatan persentase pada kategori kurang dibandingkan tahun-tahun sebelumnya. Hal ini mengindikasikan adanya penurunan semangat kerja yang berdampak pada kinerja mereka namun hal ini perlu diteliti lebih lanjut.

Permasalahan mengenai rendahnya semangat kerja karyawan haruslah diatasi sedini mungkin. Karyawan harus selalu diupayakan untuk bekerja dengan baik dan selalu antusias dalam mengerjakan tugas- 
tugasnya semaksimal mungkin untuk mencegah terjadinya penurunan kinerja.

Employee engagement menjadi isu yang menarik dalam pembahasan mengenai perilaku organisasi dalam beberapa tahun terakhir. Daya tarik ini timbul karena employee engagement berpengaruh pada kinerja perusahaan secara keseluruhan dan merupakan kunci keberhasilan dan profitabilitas organisasi (Ott, 2007).

Bowles \& Cooper (2009) mengatakan bahwa karyawan yang merasa engaged, akan melakukan beberapa tindakan seperti: advocacy

(merekomendasikan organisasinya sebagai tempat bekerja yang baik atau merekomendasikan barang dan jasa yang dihasilkan); "going the extra mile" (tidak langsung pulang ketika jam kerja berakhir, tetap mengusahakan agar kebutuhan pelanggan dapat terpenuhi); menjadi relawan dalam menyelesaikan suatu tugas; menunjukkan rendahnya penentangan dan sebagainya.

Engagement pada karyawan akan muncul ketika karyawan memiliki semangat kerja yang tinggi. Hal ini sesuai dengan pendapat Bowles \& Cooper (2009) yang mengatakan bahwa engagement merupakan hasil dari semangat kerja yang tinggi, Lebih jauh dikatakan bahwa ketika kondisi lingkungan dipersepsikan positif baik secara fisik maupun psikososial maka karyawan akan mengalami perasaan sejahtera yang membangkitkan semangat kerja, ia akan bekerja dengan penuh antusias untuk menghasilkan yang lebih banyak dan lebih baik. Ketika semangat kerja pada level yang tinggi, maka akan memicu perilaku karyawan yang telah dijelaskan diatas tadi (advocacy, going to the extra mile, menolong orang lain, komitmen dsb). Perilaku karyawan inilah yang disebut dengan perilaku karyawan yang memiliki engagement.

Selanjutnya dikatakan bahwa engagement tidak mungkin ada tanpa semangat kerja yang tinggi, dan semangat kerja yang tinggi biasanya menghasilkan engagement (Bowles \& Cooper, 2009). Dengan kata lain, semangat kerja merupakan aspek yang harus muncul terlebih dahulu pada diri karyawan sebelum karyawan merasa engaged.

Semangat kerja yang dimiliki oleh setiap karyawan merupakan sikap mental yang mampu memberikan dorongan bagi seseorang untuk dapat bekerja lebih giat, cepat, dan baik. Semangat kerja karyawan yang tinggi akan berpengaruh terhadap efisiensi kerja dan efektivitas kerja.

Melihat pentingnya semangat kerja dengan kaitannya terhadap employee engagement, maka peneliti tertarik untuk mengkaji semangat kerja yang dimiliki karyawan PT. Perkebunan X serta pengaruhnya terhadap employee engagement. Hasil penelitian ini akan digunakan untuk menentukan intervensi yang tepat dalam meningkatkan employee engagement melalui peningkatan semangat kerja karyawan PT. Perkebunan X.

Dari latar belakang penelitian diatas, rumusan masalah dalam penelitian ini yaitu: bagaimana gambaran employee engagement dan semangat kerja karyawan PT. Perkebunan $X$ dan seberapa besar pengaruh antara semangat kerja dengan employee engagement pada karyawan PT. Perkebunan X.

\section{Kajian Literatur}

\section{Employee Engagement}

Gallup Oranization menyatakan bahwa karyawan yang mempunyai nilai engagement merupakan pekerja yang 
memiliki keterlibatan secara penuh serta antusias terhadap pekerjaan mereka (Tritch, 2003). Definisi ini sejalan dengan definisi yang dikemukakan oleh Harter dkk (2002) yang menyatakan engagement sebagai keterlibatan seorang karyawan serta kepuasan pada pekerjaan yang dilengkapi dengan antusiasme. Dvir, Eden, Avolio \& Shamir (2002) mendefinisikan engagement dalam istilah "high level of activity, initiative and responsibility". Secara lebih spesifik Schaufeli, Salanova, Gonzalez-Roma dan Bakker (2002) mendefinisikan employee engagement sebagai positivitas, pemenuhan, kerja dari pusat pikiran yang dikarakteristikkan dengan vigor, dedication dan absorption. Pengertian employee engagement ini juga dikemukakan oleh Robinson, Perryman \& Hayday (2004) yang mendefinisikan keterikatan karyawan sebagai sikap positif individu karyawan terhadap organisasi dan nilai organisasi. Seorang karyawan yang memiliki tingkat keterikatan tinggi pada organisasi memiliki pemahaman dan kepedulian terhadap lingkungan operasional organisasi, mampu bekerja sama untuk meningkatkan pencapaian unit kerja/organisasi melalui kerja sama antara individu karyawan dengan manajemen. Employee engagement juga dikaitkan dengan dorongan motivasi internal yang tinggi (Colbert, Mount, Harter, Witt \& Barrick, 2004). Hal ini sejalan dengan Wellins dan Concelman (dalam Little \& Little, 2006) yang mengatakan bahwa employee engagement adalah dorongan ilusi yang memotivasi karyawan untuk menunjukkan performance yang tinggi. Dorongan ini merupakan gabungan dari komitmen, loyalitas, produktivitas dan kepemilikan. Definisi ini kemudian ditambahkan dengan memasukkan perasaan dan sikap karyawan terhadap pekerjaannya dan organisasi.

Dari beberapa pendapat para ahli diatas, dapat disimpulkan bahwa keterikatan karyawan adalah sikap positif individu karyawan terhadap organisasi dan nilai organisasi yang ditunjukkan dengan adanya komitmen, dedikasi dan loyal kepada organisasi, atasan, pekerjaan dan rekan kerjanya. Seorang karyawan yang memiliki tingkat keterikatan yang tinggi pada organisasi memiliki pemahaman dan kepedulian terhadap lingkungan operasional organisasi, antuasias dalam bekerja, mampu bekerja sama dengan karyawan lain, berbicara positif mengenai organisasi, dan berbuat melebihi harapan organisasi.

\section{Tipe Karyawan berdasarkan tingkat Employee Engagement}

Seorang karyawan yang engaged akan merasa loyal dan peduli dengan masa depan organisasinya. Karyawan tersebut memiliki kesediaan untuk melakukan usaha ekstra demi tercapainya tujuan organisasi untuk tumbuh dan berkembang. Gallup (2004) mengelompokkan 3 jenis karyawan berdasarkan tingkat engagement yaitu:

\section{Engaged}

Karyawan yang engaged adalah seorang pembangun (builder). Mereka selalu menunjukkan kinerja dengan level yang tinggi. Karyawan ini akan bersedia menggunakan bakat dan kekuatan mereka dalam bekerja setiap hari serta selalu bekerja dengan gairah dan selalu mengembangkan inovasi agar perusahaan berkembang. 


\section{Not Engaged}

Karyawan dalam tipe ini cenderung fokus terhadap tugas dibandingkan untuk mencapai tujuan dari pekerjaan itu. Mereka selalu menunggu perintah dan cenderung merasa kontribusi mereka diabaikan.

\section{Actively Disengaged}

Karyawan tipe ini adalah penunggu gua "cave dweller". Mereka secara konsisten menunjukkan perlawanan pada semua aspek. Mereka hanya melihat sisi negatif pada berbagai kesempatan dan setia harinya, tipe actively disengaged ini melemahkan apa yang dilakukan oleh pekerja yang engaged.

\section{Dimensi Employee Engagement}

Menurut Macey, Schneider, Barbera \& Young (2009) employee engagement mencakup 2 dimensi penting, yaitu:

1. Employee engagement sebagai energi psikis. Karyawan merasakan pengalaman puncak (peak experience) dengan berada di dalam pekerjaan dan arus yang terdapat di dalam pekerjaan tersebut. Employee engagement merupakan keseriusan ketika larut dalam pekerjaan (immersion), perjuangan dalam pekerjaan (striving), penyerapan (absorption), fokus (focus) dan juga keterlibatan (involvement).

2. Employee engagement sebagai energi tingkah laku. Bagaimana employee engagement terlihat oleh orang lain. Employee engagement terlihat oleh orang lain dalam bentuk tingkah laku yang berupa hasil. Tingkah laku yang terlihat dalam pekerjaan berupa:

a. Karyawan akan berfikir dan bekerja secara proaktif, akan mengantisipasi kesempatan untuk mengambil tindakan dan akan mengambil tindakan dengan cara yang sesuai dengan tujuan organisasi.

b. Karyawan yang engaged tidak terikat pada "job description", mereka fokus pada tujuan dan mencoba untuk mencapai secara konsisten mengenai kesuksesan organisasi.

c. Karyawan secara aktif mencari jalan untuk dapat memperluas kemampuan yang dimiliki dengan jalan yang sesuai dengan visi dan misi perusahaan.

d. Karyawan pantang menyerah walau dihadapkan dengan rintangan atau situasi yang membingungkan.

\section{Faktor yang Menyebabkan Employee Engagement dan Disengagement}

Vazirani, (2007) mengemukakan bahwa ada beberapa faktor penting yang menyebabkan employee engagement, yaitu:

1. Pengembangan karir - kesempatan untuk pengembangan pribadi Organisasi dengan tingkat engagement yang tinggi memberikan kesempatan kepada karyawan untuk mengembangkan kemampuan mereka, mempelajari keahlian baru, mendapatkan pengalaman baru dan menyadari potensi karyawan mereka. Ketika organisasi merancang jenjang karir bagi karyawan mereka dan mengembangkan pelaksanaannya bagi karyawan, maka karyawan juga akan menjadi investasi bagi perusahaan.

2. Pengembangan karir - manajemen yang efektif dari potensi atau bakat individu. Pengembangan karir mempengaruhi keterikatan karyawan dan mempertahankan karyawan yang paling 
berbakat dan menyediakan kesempatan bagi pengembangan pribadi.

3. Kepemimpinan - kejelasan dari nilai perusahaan Nilai inti organisasi jelas dan tidak ambigu.

4. Kepemimpinan - perlakuan yang penuh hormat kepada karyawan Organisasi menunjukkan respek pada setiap kualitas dan kontribusi dari karyawan tanpa memperhatikan level mereka.

5. Kepemimpinan - standar perilaku etis sesuai standar perusahaan Standar etika organisasi juga menyebabkan karyawan engage.

6. Pemberdayaan - karyawan ingin dilibatkan dalam keputusan yang mempengaruhi kerja mereka. pemimpin dari tempat kerja yang memiliki keterikatan tinggi menciptakan lingkungan yang menantang dan penuh rasa percaya, dimana karyawan dibiarkan berinovasi untuk memajukan organisasi.

7. Image - seberapa besar karyawan untuk memberikan dukungan pada produk dan jasa yang dihasilkan organisasinya tergantung pada luasnya persepsi pelanggan terhadap barang dan jasa yang dihasilkan organisasinya tersebut.

\section{Semangat Kerja}

Semangat kerja merupakan terjemahan dari kata morale yang artinya moril atau semangat juang (Echols \& Shadily,1997). Beach (1980) mendefinisikan semangat kerja sebagai sikap individu dalam kelompok terhadap lingkungan kerjanya dan bekerja sama secara sukarela mengerahkan kemampuannya untuk mencapai tujuan organisasi. Pendapat lain mengatakan bahwa semangat kerja merupakan perasaan yang memungkinkan seseorang bekerja untuk menghasilkan yang lebih banyak dan lebih baik (Halsey, 2003). Sementara menurut Kossen (1993) semangat kerja adalah suasana yang ditimbulkan oleh sikap kerja dari para anggota suatu organisasi. Nitisemito (1996) mengatakan bahwa semangat kerja adalah melakukan pekerjaan secara lebih giat sehingga pekerjaan dapat diharapkan lebih cepat dan lebih baik. Sastrohadiwiryo (2002) mengatakan bahwa semangat kerja dapat diartikan sebagai suatu kondisi mental, atau perilaku individu tenaga kerja dan kelompok-kelompok yang menimbulkan kesenangan yang mendalam pada diri tenaga kerja untuk bekerja dengan giat dan konsekuen dalam mencapai tujuan yang telah ditetapkan perusahaan. Pengertian semangat kerja juga dikemukakan oleh Davis \& Newstrom (2000) yang menyatakan bahwa semangat kerja adalah kesediaan perasaan maupun perilaku yang memungkinkan seseorang bekerja untuk menghasilkan kerja lebih banyak dan lebih baik. Semangat kerja merupakan suasana kerja yang positif yang terdapat dalam suatu organisasi dan terungkap dalam sikap individu maupun kelompok yang mendukung seluruh aspek kerja termasuk di dalamnya lingkungan, kerjasama dengan orang lain yang secara optimal sesuai dengan kepentingan dan tujuan perusahaan. Menurut Winardi (2004) semangat kerja mengandung pengertian ketiadaan konflik, perasaan senang, penyesuaian pribadi secara baik, dan tingkat keterlibatan ego dalam pekerjaan.

Berdasarkan para ahli diatas, dapat disimpulkan bahwa semangat kerja adalah sikap pekerja dalam mencapai tujuan organisasi yang harus ditunjukkan dengan 
bekerja penuh energi, antusias, dan memiliki rasa kebersamaan.

\section{Faktor yang Mempengaruhi Semangat Kerja}

Bowles dan Cooper (2009) mengemukakan ada beberapa faktor yang mempengaruhi semangat kerja karyawan, yaitu:

1. Pekerjaan itu sendiri dan image organisasi

Hal ini termasuk bagaimana karyawan melihat organisasi dan pekerjaan mereka serta bagaimana ia berpikir mengenai orang lain (masyarakat dan pelanggan) akan melihat organisasi tempat dia berada.

2. Kompensasi dan benefit

Hal ini mencakup pembayaran upah serta benefit lain yang diberikan oleh organisasi.

3. Karir dan pengembangan

Merupakan aspek yang berhubungan dengan kesempatan untuk berprestasi, keadilan dalam proses promosi, perekrutan secara internal maupun eksternal, kesempatan mendapatkan pelatihan dan pengembangan dalam upaya meningkatkan kemampuan dan pengetahuan.

\section{Keselamatan kerja}

Perasaan aman yang didapatkan oleh karyawan dalam bekerja, dan adanya jaminan bahwa organisasi akan terus bertahan dan berkembang.

5. Komunikasi

Mencakup seluruh informasi yang diberikan kepada karyawan, apa informasi itu penting, apakah informasi tersebut dapat dipercaya, apakah cara penyampaiannya sesuai.

6. Produktifitas

Bagaimana cara karyawan menjadi produktif, apakah sudah cukup diarahkan atau tidak, ketiadaan atau kurangnya pelatihan yang diberikan, kebijaksanaan dari manajemen, bagaimana desain alur kerja dan apakah seseorang mendapatkan beban kerja yang lebih banyak dibanding kan orang lain tanpa mendapatkan konsekuensi.

\section{Kondisi kerja}

Hal ini termasuk kondisi kerja secara fisik, keselamatan, perlengkapan dan peralatan yang memadai, pengaturan jarak ruangan kantor, fasilitas kesehatan dan aspek yang berhubungan.

8. Manajemen dan pengawasan

Bagaimana karyawan melihat atasannya, apa yang diharapkan oleh pimpinan untuk karyawan lakukan atau kerjakan, bagaimana image pimpinan yang dilihat oleh karyawan, apakah perlakuan manajer atau pimpinan adil atau tidak, kapan terakhir kali karyawan mendapat masukan dari atasan atas kinerjanya, dan apakah masukan tersebut mampu memotivasinya.

9. Pengambilan keputusan

Mencakup bagaimana suatu keputusan dibuat, apakah sudah sesuai atau belum, apakah keputusan itu berkualitas dsb.

Menurut Anoraga dan Suyati (1995), bahwa terdapat beberapa aspek yang dapat digunakan untuk mengukur semangat kerja antara lain:

\section{Kerjasama}

Kerjasama berarti bekerja bersamasama ke arah tujuan yang sama dimana setiap orang bekerja dan mengembangkan tenaganya dengan ikhlas tanpa bersungutsungut dan rasa malas. Selanjutnya Anoraga menyatakan bahwa kerjasama dapat dilihat dari beberapa hal yaitu:

a. Kesediaan para karyawan untuk bekerjasama dengan teman-teman sekerja maupun dengan atasan mereka yang berdasarkan tujuan bersama 
b. Kesediaan untuk saling membantu di antara teman sekerja sehubungan dengan tugasnya.

\section{Disiplin Kerja}

Disiplin kerja merupakan sikap dimana seorang pegawai dituntut untuk mematuhi ketentuan-ketentuan organisasi secara sadar sehingga menjadi kebiasaan yang berlaku di dalam pelaksanaan kerja sehari-hari. Mematuhi secara sadar berarti sudah tertanam adanya unsur pengendalian diri dalam mengimplementasikan apa yang telah disadari itu. Adanya sikap pengendalian berarti sudah menunjukkan adanya sikap mental dan moral yang tinggi yang melekat pada diri seseorang.

\section{Kegairahan Kerja}

Kegairahan kerja merupakan unsur penting dalam rangka terselesaikannya suatu tugas, karena setiap pemimpin harus dapat meningkatkan dan berusaha untuk membangkitkan kegairahan kerja karyawannya. Menurut Anoraga dan Suyati (1995), bahwa untuk mengetahui pelaksanaan kerja bawahan yang dilakukan dengan bergairah dapat dilihat dari beberapa hal:

a. Karyawan dalam melaksanakan pekerjaan dengan disertai perasaan gembira dan senang hati serta rela berkorban tanpa banyak perintah.

b. Karyawan dalam menyelesaikan pekerjaan dengan penuh perhatian tanpa mengeluh dan bermalasmalasan.

c. Karyawan selalu mengisi waktu kosong dengan bekerja.

\section{Metode Penelitian}

Metode penelitian sangat menentukan suatu penelitian karena menyangkut cara yang benar dalam pengumpulan data, analisa data dan pengambilan keputusan hasil penelitian. Pembahasan dalam metode penelitian meliputi identifikasi variabel penelitian, definisi operasional, subyek penelitian, prosedur penelitian, dan metode analisis (Hadi, 2000).

Variabel Tergantung pada penelitian ini adalah Employee Engagement yang didefnikan sebagai sikap positif karyawan yang ditunjukkan dengan kepedulian terhadap organisasi, antuasias dalam bekerja dan mampu bekerja sama dengan karyawan lain. Employee engagement diukur dengan menggunakan dimensi yang dikemukakan oleh Macey, Schneider, Barbera, \& Young (2009) yaitu employee engagement sebagai energi psikis dan sebagai energi tingkah laku.

Skor total yang diperoleh pada skala employee engagement menggambarkan tingkat engagement pada karyawan yang dibagi atas 3 kategori yaitu tinggi, sedang dan rendah. Kategori ini selanjutnya akan dikelompokkan untuk melihat tipe karyawan berdasarkan tingkat engagement seperti yang dikelompokkan oleh Gallup (2004) yaitu: Engaged, Not Engaged dan Actively Disengaged.

Selanjutnya Variable Bebas pada penelitian ini adalah Semangat Kerja yang didefinisikan sebagai sikap pekerja dalam mencapai tujuan organisasi yang harus ditunjukkan dengan bekerja penuh energi, antusias, dan memiliki rasa kebersamaan. Semangat kerja diukur dengan menggunakan skala yang dibuat berdasarkan dimensi yang digunakan untuk mengukur semangat kerja dari Anoraga dan Suyati (1995) yaitu: kerjasama, disiplin kerja dan kegairahan kerja. 
Skor total yang diperoleh pada skala semangat kerja menggambarkan semangat kerja karyawan. Semakin tinggi skor skala semangat kerja yang diperoleh karyawan, menunjukkan semakin tinggi semangat kerja karyawan. Sebaliknya, semakin rendah skor skala semangat kerja yang diperoleh karyawan menunjukkan semakin rendah semangat kerja karyawan.

Teknik pengambilan sampel yang digunakan dalam penelitian ini adalah purposive sampling yaitu pengambilan sampel dengan tidak memberi kesempatan merupakan model penskalaan pernyataan sikap yang menggunakan distribusi respons sebagai dasar penentuan nilai sikap (Azwar, 2004). Ada dua skala yang digunakan dalam penelitian ini, yaitu skala employee engagement dan skala semangat kerja. Skala Employee engagement diukur dengan menggunakan skala yang dibuat berdasarkan dimensi employee engagement oleh Macey, Schneider, Barbera \& Young (2009). Skor total yang diperoleh pada skala employee engagement menggambarkan tingkat engagement pada

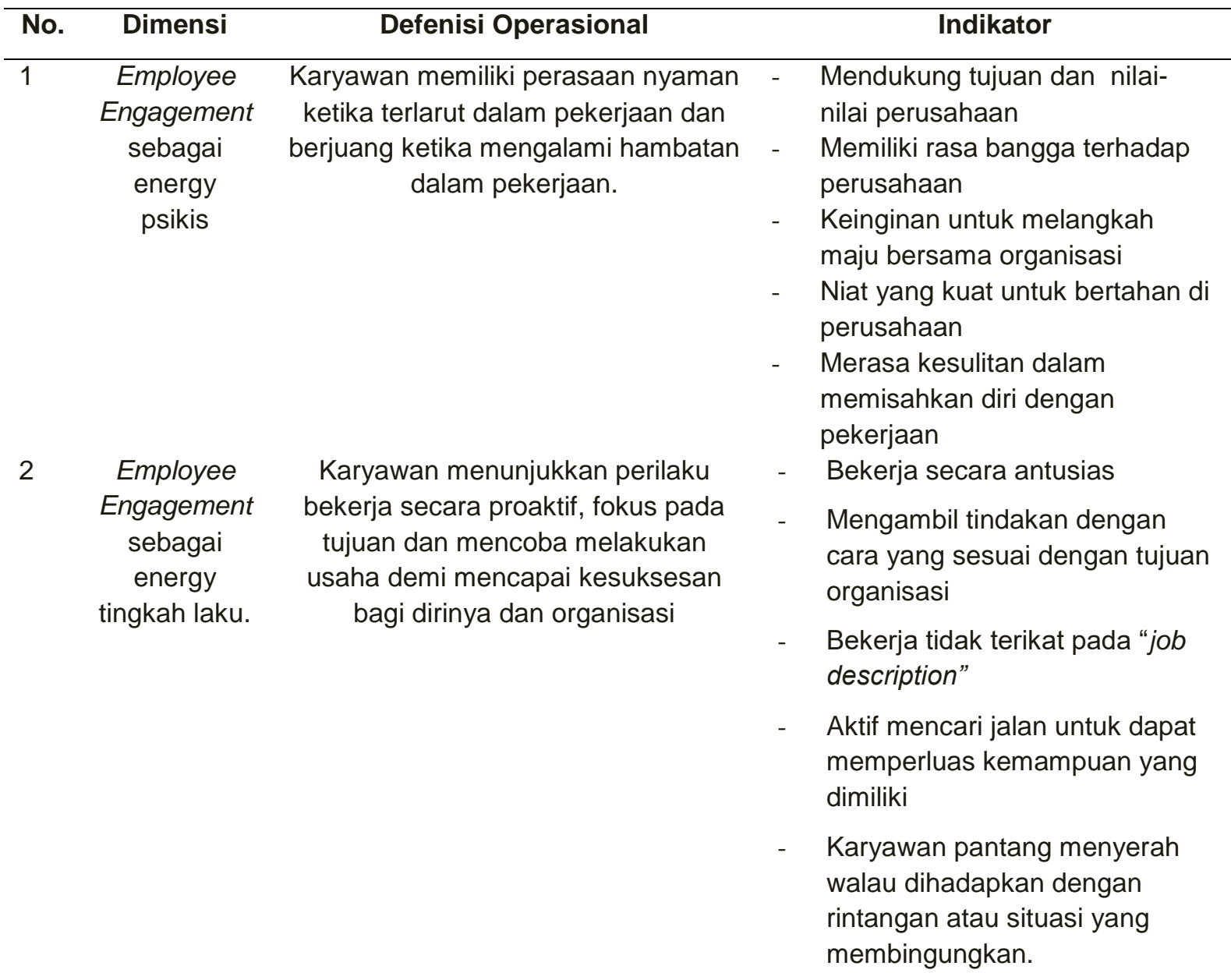

yang sama kepada seluruh anggota populasi serta menetapkan tujuan tertentu pada sampelnya Sampel dalam penelitian ini adalah karyawan kantor pusat PT. Perkebunan X yang berjumlah 42 orang.

Penelitian ini menggunakan penskalaan model Likert. Penskalaan ini karyawan yang dibagi atas 3 kategori yaitu tinggi, sedang dan rendah. Kategori ini selanjutnya akan dikelompokkan untuk melihat tipe karyawan berdasarkan tingkat engagement seperti yang dikelompokkan oleh Gallup (2004) yaitu: Engaged, Not Engaged dan Actively Disengaged. 
Skala semangat kerja disusun berdasarkan 3 aspek yang dikemukakan oleh Anoraga \& Suyati (1995) yaitu: Kerjasama, Disiplin Kerja dan Kegairahan Kerja.

\begin{tabular}{|c|c|c|c|}
\hline No & $\begin{array}{c}\text { Dimen- } \\
\text { si }\end{array}$ & $\begin{array}{c}\text { Definisi } \\
\text { Operasional }\end{array}$ & Indikator \\
\hline 1 & $\begin{array}{l}\text { Kerja } \\
\text { sama }\end{array}$ & $\begin{array}{l}\text { Karyawan } \\
\text { memiliki rasa } \\
\text { saling } \\
\text { ketergantungan } \\
\text { dan saling } \\
\text { mendukung yang } \\
\text { kuat satu sama } \\
\text { lain } \\
\text { mencapai tujuan } \\
\text { bersama }\end{array}$ & $\begin{array}{l}\text {-Karyawan } \\
\text { memiliki } \\
\text { kesediaan } \\
\text { untuk } \\
\text { bekerjasam } \\
\text { a dengan } \\
\text { karyawan } \\
\text { lain } \\
\text {-Karyawan } \\
\text { mau } \\
\text { embantu } \\
\text { karyawan } \\
\text { lain dalam } \\
\text { bekerja }\end{array}$ \\
\hline 2 & Disiplin & $\begin{array}{l}\text { Karyawan } \\
\text { memiliki rasa } \\
\text { patuh terhadap } \\
\text { aturan baik } \\
\text { tertulis maupun } \\
\text { yang tidak tertulis } \\
\text { didalam } \\
\text { perusahaan }\end{array}$ & $\begin{array}{l}\text {-Karyawan } \\
\text { mematuhi } \\
\text { aturan jam } \\
\text { kerja yang } \\
\text { dibuat } \\
\text { perusahaan } \\
\text { - Karyawan } \\
\text { mematuhi } \\
\text { aturan } \\
\text { penggunaan } \\
\text { fasilitas } \\
\text { perusahaan }\end{array}$ \\
\hline 3 & $\begin{array}{l}\text { Kegai- } \\
\text { rahan }\end{array}$ & $\begin{array}{l}\text { Karyawan } \\
\text { memiliki hasrat } \\
\text { dan gairah dalam } \\
\text { bekerja sebaik } \\
\text { mungkin. }\end{array}$ & $\begin{array}{l}\text {-Karyawan } \\
\text { bekerja } \\
\text { dengan giat } \\
\text { dan antusias } \\
\text { - Karyawan } \\
\text { tidak mudah } \\
\text { lelah dan } \\
\text { tetap fokus } \\
\text { dalam } \\
\text { bekerja }\end{array}$ \\
\hline
\end{tabular}

\section{Validitas, Reliabilitas dan Uji Daya Beda Aitem}

Uji validitas yang digunakan pada penelitian ini adalah validitas isi, yaitu berkaitan dengan apakah aitem mewakili pengukuran dalam area isi sasaran yang diukur. Validitas isi merupakan hal utama dalam suatu tes yang biasanya dinilai dengan menggunakan pertimbangan pakar (proffesional judgement) (Azwar, 2005).

Uji reliabilitas alat ukur ini menggunakan pendekatan konsistensi internal yaitu single trial administration yang artinya menggunakan satu bentuk tes yang dikenakan sekali saja pada sekelompok subjek. Pendekatan ini dipandang ekonomis, praktis, dan berefisiensi tinggi (Azwar, 2005). Formula statistika yang digunakan untuk menguji reliabilitas alat ukur adalah Alpha Cronbach dengan bantuan komputer dari program SPSS 16.00 for Windows yang nantinya akan menghasilkan reabilitas dari Skala Semangat Kerja dan Employee Engagement.

Daya beda aitem pada penelitian ini dilihat dengan menggunakan koefisien korelasi Pearson Product Moment dengan bantuan komputer dari program SPSS version 16.00 for windows. Prosedur pengujian ini akan menghasilkan koefisien korelasi aitem total yang dikenal dengan indeks daya beda aitem. Semakin tinggi koefisien korelasi positif antara skor aitem dengan skor skala berarti semakin tinggi daya beda aitem tersebut. Bila koefisien korelasinya rendah mendekati nol berarti fungsi aitem tersebut tidak cocok dengan fungsi ukur skala daya bedanya tidak baik. Aitem yang digunakan adalah aitem yang memiliki nilai $r \geq 0.3$ (Azwar, 2005). Pada skala employee engagement jumlah aitem yang diuji cobakan adalah 30 aitem dan dari 30 aitem diperoleh 17 aitem yang sahih dan 13 aitem yang gugur. Data dari 17 aitem inilah yang akan digunakan dalam penelitian, dengan kisaran koefisien korelasi $r_{x y}=0.311$ sampai dengan $r_{x y}=$ 0.812 dan reliabilitas tes $\left(r_{\mathrm{xx}}\right)$ sebesar 0.9. 
Distribusi aitem yang sahih dari skala employee engagement dapat dilihat pada tabel berikut.

Tabel 4. Jumlah aitem skala employee engagement setelah analisa

\begin{tabular}{lll}
\hline No. & \multicolumn{1}{c}{ Dimensi } & \multicolumn{1}{c}{ Jumlah } \\
\hline 1. & Sebagai energi psikis; & $\mathbf{7}$ \\
2. & Sebagai energi tingkah laku: & $\mathbf{1 0}$ \\
& TOTAL & $\mathbf{1 7}$ \\
\hline
\end{tabular}

Hasil uji coba skala Semangat Kerja jumlah aitem yang teliti adalah 25 aitem dan dari 25 aitem diperoleh 14 aitem yang sahih dan 11 aitem yang gugur. Kemudian 14 aitem tersebut dianalisa kembali dan hasilnya 14 aitem tersebut memiliki harga kritik diatas 0.3 dengan kisaran koefisien korelasi $r_{x y}=0.389$ sampai dengan $r_{x y}=$ 0.84 dan reliabilitas alat ukur $\left(r_{\mathrm{xx}}\right)$ sebesar 0.885. Distribusi aitem yang sahih dari skala semangat kerja dapat dilihat pada tabel berikut:

Tabel 5. Jumlah aitem skala semangat kerja setelah analisa

\begin{tabular}{ccc}
\hline No & Aspek & Total \\
\hline 1 & Kerjasama & $\mathbf{5}$ \\
2 & Disiplin & $\mathbf{3}$ \\
3 & Kegairahan & $\mathbf{6}$ \\
& TOTAL & $\mathbf{1 4}$ \\
\hline
\end{tabular}

Untuk menguji hipotesis pada penelitian ini menggunakan metode análisis regresi sederhana. Regresi adalah suatu proses memperkirakan secara sistematis tentang apa yang paling mungkin terjadi di masa yang akan datang berdasarkan informasi masa lalu dan masa sekarang agar kesalahannya dapat diperkecil. Kegunaan regresi dalam penelitian salah satunya adalah untuk meramalkan (memprediksikan) variabel terikat (Y) apabila variabel bebas (X). Persamaan yang digunakan adalah:

$$
\mathrm{Y}=\mathrm{a}+\mathrm{bX}
$$

Keterangan :

$\mathrm{Y}=$ variabel terikat (dependen variabel)

$\mathrm{X}=$ variabel bebas (independen variabel)

$$
\begin{aligned}
& \mathrm{a}=\text { nilai konstanta } \\
& \mathrm{b}=\text { koefisien regresi }
\end{aligned}
$$

Keseluruhan analisa dilakukan dengan menggunakan fasilitas komputerisasi SPSS 16.0 for Windows. Sebelum data-data yang terkumpul dianalisa, terlebih dahulu dilakukan uji asumsi yang meliputi:

\section{Uji normalitas}

Uji normalitas ini dilakukan dengan menggunakan uji one sample kolmogorovsmirnov. Data dikatakan terdistribusi normal jika harga $\mathrm{p}>0.05$.

1. Berdasarkan uji normalitas variabel employee engagement diperoleh sebaran normal $\mathrm{Z}=1.218$ dengan $\mathrm{p}>0.05(\mathrm{p}=0.103)$, dengan demikian dapat dikatakan variabel employee engagement mengikuti sebaran normal.

2. Berdasarkan uji normalitas variabel semangat kerja diperoleh sebaran normal $\mathrm{Z}=1.152$ dengan $\mathrm{p}>0.05$ $(\mathrm{p}=0.141)$, dengan demikian dapat dikatakan variabel semangat kerja mengikuti sebaran normal.

Tabel 6. Hasil Uji Normalitas

\begin{tabular}{lll}
\hline \multicolumn{1}{c}{ Variabel } & \multicolumn{1}{c}{ Sig. } \\
\hline Employee Engagement & 0.103 & \\
Semangat Kerja & 0141 & \\
\hline
\end{tabular}

\section{Uji linearitas}

Uji ini merupakan persyaratan apakah model regresi dapat digunakan untuk 
menganalisis data. Untuk menentukan kelinieran garis regresi dapat ditentukan dengan melihat nilai p. Kriteria yang digunakan adalah apabila nilai $\mathrm{p}<0.05$ maka persamaan garis regresi disebut linier. Analisis hasil perhitungannya dapat terlihat pada tabel. Dari hasil uji linearitas diperoleh nilai $\mathrm{F}=44.288$ dan $\mathrm{p}=0.00$, nilai ini kurang dari 0.05 . Hal ini berarti persamaan garis regresi linear.

\section{Tabel 7. Uji Linearitas}

\begin{tabular}{lcc}
\hline \multicolumn{1}{c}{ Variabel } & Linearity & $\begin{array}{c}\text { Deviation } \\
\text { from linearity }\end{array}$ \\
\hline $\begin{array}{l}\text { Employee } \\
\text { Engagement }\end{array}$ & 0.000 & 0.000 \\
$\begin{array}{l}\text { Semangat } \\
\text { Kerja }\end{array}$ & 0.026 & 0.026 \\
\hline
\end{tabular}

\section{Hasil dan Pembahasan}

Tujuan dari penelitian ini adalah untuk melihat pengaruh semangat kerja terhadap employee engagement serta melihat besarnya kontribusi variabel bebas terhadap variabel tergantung. Uji hipotesis penelitian ini dilakukan dengan analisa regresi. Kriteria yang digunakan apabila nilai $\mathrm{p}<0.05$ maka kedua variabel memiliki pengaruh yang signifikan. Hasil perhitungan Analisa Regresi dapat dilihat dalam tabel berikut.

Tabel 8. Hasil Perhitungan Analisa Regresi

\begin{tabular}{lcc}
\hline \multicolumn{1}{c}{ Model } & \multicolumn{1}{c}{ F } & \multicolumn{1}{c}{ Sig. } \\
\hline 1 Regression & 31.031 & $.000^{\mathrm{a}}$ \\
Residual & & \\
Total & & \\
\hline
\end{tabular}

Pada tabel dapat dilihat nilai signifikansi adalah 0.000 , dengan kriteria $\mathrm{p}<0.05$ maka dapat dikatakan bahwa semangat kerja memiliki pengaruh terhadap employee engagement. Selanjutnya dilihat bagaimana arah kedua variable serta seberapa besar sumbangan efektif semangat kerja terhadap employee engagement. Hasil perhitungan dapat dilihat dalam tabel berikut:

Tabel 9. Sumbangan Efektif Variabel Semangat Kerja

\begin{tabular}{lcc}
\multicolumn{1}{c}{ Variabel } & $\mathbf{R}$ & R Square \\
\hline Employee & & \\
Engagement * & $.661^{\mathrm{a}}$ & .437 \\
Semangat Kerja & & \\
\hline
\end{tabular}

Dengan melihat nilai $\mathrm{R}=0.661$ yang bertanda positif maka dapat dikatakan bahwa hubungan variabel semangat kerja terhadap employee engagement adalah searah, yang artinya semakin tinggi semangat kerja maka employee engagement juga akan semakin tinggi begitu juga sebaliknya. Dari tabel dapat dilihat bahwa koefisien determinan ( $R$ Square) adalah sebesar 0.437, hal ini berarti bahwa semangat kerja dapat menjelaskan $43.7 \%$ variabel employee engagement.

Model Persamaan regresi dapat dibuat dengan melihat tabel berikut:

Tabel 10. Model Persamaan Regresi

\begin{tabular}{cc}
\hline \multicolumn{1}{c}{ Variabel } & B \\
\hline Employee Engagement & 19.883 \\
Semangat Kerja & .710 \\
\hline \multicolumn{2}{c}{ Pada tabel dapat diketahui bahwa nilai }
\end{tabular}
koefisien konstanta B adalah 19.883 dan nilai koefisien variable adalah 0.710 sehingga model persamaan regresi estimasi linier yang diperoleh adalah sebagai berikut:

$$
Y=19.883+0.710 X
$$


Dari persamaan garis diatas, dapat diartikan bahwa bila variabel $\mathrm{X}$ diganti dengan suatu satuan akan menyebabkan peningkatan pada variabel $Y$. Hal ini berarti jika variabel semangat kerja bernilai 1, maka employee engagement adalah sebesar 20.593 satuan.

Hasil penelitian ini memperkuat apa yang telah dikemukakan oleh Bowles \& Cooper (2009) yang menyatakan bahwa engagement merupakan hasil dari semangat kerja yang tinggi, lebih jauh dikatakan bahwa ketika kondisi lingkungan dipersepsikan positif baik secara fisik maupun psikososial maka karyawan akan mengalami perasaan sejahtera yang membangkitkan semangat kerja, ia akan bekerja dengan penuh antusias untuk menghasilkan yang lebih banyak dan lebih baik. Ketika semangat kerja pada level yang tinggi, maka akan memicu perilaku karyawan yang memiliki engagement.

Ada beberapa alasan yang menyebabkan hubungan positif antara semangat kerja dengan employee engagement, yaitu:

Pertama, semangat kerja semangat kerja adalah kesediaan perasaan maupun perilaku yang memungkinkan seseorang bekerja untuk menghasilkan kerja lebih banyak dan lebih baik (Davis \& Newstrom, 2000). Seorang karyawan yang memiliki semangat kerja yang tinggi akan bekerja dengan energik, antusias dan penuh dengan kemauan untuk menyelesaikan pekerjaannya. Karyawan ingin datang bekerja dan antusias untuk bekerja ketika sampai di kantor (Carlaw, Deming, dan Friedman, 2003). Gejala ini menurut Marciano (2010) merupakan prilaku khusus dari seorang karyawan yang memiliki rasa keterikatan atau employee engagement.
Kedua, semangat kerja dapat dideskripsikan sebagai hubungan antara seorang karyawan dengan tempat kerjanya (Hasan \& Subhani, 2011). Ketika karyawan memiliki semangat kerja yang tinggi, maka akan menghasilkan kinerja dan produktifitas yang positif (Youssef dalam Hasan \& Subhani, 2011). Morris \& Sherman (1981) juga menyatakan bahwa karyawan yang memiliki semangat kerja yang tinggi menunjukkan adanya komitmen ketika bekerja dalam kelompok. Letak komitmen ini sendiri merupakan salah satu aspek penyusun dalam employee engagement (Robinson dan Hayday dalam Rastogi, 2012). Hal ini yang menyebabkan semangat kerja menunjukkan hubungan positif dengan employee engagement.

Selain itu, perusahaan juga mengharapkan karyawan yang memiliki semangat kerja yang tinggi, sebab karyawan yang memiliki semangat kerja yang tinggi adalah karyawan yang bekerja dengan berenergi, antusias, dan memiliki rasa kebersamaan. Karyawan yang memiliki semangat kerja rendah adalah ketika karyawan merasa bosan, berkecil hati, dan malas (Carlaw, Deming \& Friedman, 2003). Dengan melihat hasil dari tiap kategori dimana ada subjek yang masuk dalam kategori rendah untuk tiap variabel maka perlu dilakukan intervensi untuk meningkatkan semangat kerja yang akhirnya akan meningkatkan employee engagement. Intervensi yang dilakukan akan mencakup ketiga dimensi dari semangat kerja dalam bentuk pelatihan peningkatan semangat kerja.

\section{Keterbatasan Penelitian}

Penelitian ini memiliki beberapa keterbatasan yaitu: 
a. Pada pembuatan alat ukur, dimensi yang digunakan untuk pengukuran employee engagement dan semangat kerja memiliki dimensi yang hampir mirip, hal ini menyebabkan tumpang tindih antara kedua konstruk sehingga menyebabkan tingginya pengaruh antara kedua variabel.

b. Respon pada skala dibuat dengan menghilangkan pilihan jawaba Netral dan hanya menyediakan 4 pilihan jawaban yaitu Sangat Setuju, Setuju, Tidak Setuju dan Sangat Tidak Setuju. Hal ini membatasi subjek penelitian dalam memilih jawaban Netral dan subjek terkesan "dipaksa" harus menentukan sikap dengan memilih 4 pilihan yang ada.

\section{Kesimpulan dan saran}

Berdasarkan hasil analisa dan interpretasi data penelitian dapat ditarik kesimpulan mengenai hasil penelitian yang telah dilakukan, yaitu:

1. Ada pengaruh positif antara semangat kerja terhadap employee engagement, dimana semakin tinggi semangat kerja maka akan semakin tinggi tingkat engagement karyawan.

2. Semangat kerja memberikan kontribusi efektif sebesar $43.7 \%$ terhadap employee engagement.

Dari penelitian yang telah dilakukan dan kesimpulan yang dikemukakan, maka peneliti mengemukakan beberapa saran. Saran-saran ini diharapkan dapat berguna bagi perkembangan kelanjutan studi ilmiah mengenai employee engagement dan semangat kerja, antara lain:

\section{Saran}

\section{Metodologis}

a. Berdasarkan koefisien determinasi diketahui bahwa sumbangan efektif dari hasil penelitian variabel semangat kerja terhadap employee engagement sebesar $43.7 \%$, selebihnya dipengaruhi variabel lain yang tidak diteliti dalam penelitian ini. Bagi peneliti yang tertarik melakukan penelitian mengenai employee engagement, peneliti menyarankan untuk melihat faktor lain yang turut mempengaruhi employee engagement.

b. Penelitian selanjutnya diharapkan untuk bisa melihat semangat kerja maupun employee engagement pada perusahaan dengan jumlah karyawan yang lebih besar

c. Penelitian selanjutnya diharapkan untuk melakukan tryout atau uji coba pada skala yang akan diteliti guna mendapat aitem yang lebih sahih dalam pengukuran semangat kerja dan employee engagement.

\section{Praktis}

a. Penelitian ini menemukan bahwa employee engagement pada PT. Perkebunan X kebanyakan berada dalam kategori not engage, perusahaan dapat melakukan strategi-strategi yang dapat membuat karyawan semakin engage pada perusahaan dengan cara melakukan analisa untuk mengetahui kebutuhan karyawan yang masih belum terpenuhi dan meningkatkan beberapa aspek yang penting diperusahaan.

b. Melihat pentingnya employee engagement bagi perusahaan, untuk perusahaan lain yang sejenis dapat menerapkan pelatihan semangat kerja yang disesuaikan dengan kebutuhan 
karyawan dalam upaya meningkatkan employee engagement sehingga kinerja dan produktivitas lebih maksimal.

\section{DAFTAR PUSTAKA}

Albrecht, S. L. (2010). Handbook of

Employee Engagement:

Perspectives, Issues, Research and

Practice.United Kingdom: Edward

Elgar Publishing Ltd.

Azwar. S. (2005). Reliabilitas dan validitas. Yogyakarta: Pustaka Pelajar. . (2004). Penyusunan skala psikologi. Yogyakarta: Pustaka Pelajar.

Anoraga, P \& Suyati. (1995). Psikologi Industri dan Sosial. Jakarta : PT. Dunia Pustaka Jaya.

Bakker, A., Emmerick, V.H \& Euwama, M.C. (2005). Crossover of Burnout And Engagement In Work Teams. Work and Occupations, 33: 464-489.

Bates, Steve. (2004). Getting Engaged. http://www.shrm.org/Publications/hr magazine/EditorialContent/Pages/02 04covstory.aspx [Online: akses September 2012]

Beach, D.S. (1980). Personnel, the Management of People at Work, 4th Edition. New York : Macmillan Publishing Co, Inc.

Bowles, D \& Cooper, C. (2009). Employee Morale: Driving Performance in Challenging Times. Basingstoke: Palgrave Macmillan.

Baumruk, R. (2004). The missing link: the role of employee engagement in Business success. Workspan, Vol.47: hal. 48-52.
Cataldo, P. (2011). Focusing on Employee Engagement: How to Measure It and Improve It. https://www.kenanflagler.unc.edu/executivedevelopment/customprograms/ /media/E93A57C2D74F4 E578A8B1012E70A56FD.pdf

[Online: akses Desember 2012]

Carlaw, Deming \& Friedman 2003. Managing \& Motivating Contact Center Employees. USA : The McGraw-Hill Companies.

Chaplin. 2004. Kamus Lengkap Psikologi. Jakarta : PT Raja Grafindo Persada.

Colbert, A. E., Mount, M. K., Harter, J. K., Witt, L. A., \& Barrick, M. R. (2004). Interactive Effects Of Personality And Perceptions Of The Work Situation On Workplace Deviance. Journal of Applied Psychology. 89(4): hal. 599-609.

Crabtree, Steve. (2011). What Your Employees Need to Know. http://businessjournal.gallup.com/con tent/146996/employees-needknow.aspx [Online: Desember 2012]

Danim, S. (2004). Motivasi Kepemimpinan \& Efektifitas Kelompok. Jakarta: PT. Rineka Cipta.

Davis, K \& Newstom, J.W. (2000). Human Behavior at Work. New Delhi: Graw Hill Publishing Company Ltd.

Desai, M., Majumdar, B. \& Prabhu, G.P. (2010). Study On Employee Engagement In Two Indian Businesses. http://www.ipublishing.co.in/ajmrvol 1no1/sped12011/AJMRSP1008.pdf [Online: akses Desember 2012] 
Dessler, G.(2003). Human Resource Management Tenth Edition. New Jersey: Prentice Hall.

Dvir, Avolio, Eden \& Shamir. (2003). Impact Of Transformational Leadership On Follower Development And Performance: A field experiment. Academy of Management Journal, 45: hal.735744.

Endres, G. M \& Smoak, L.M. (2008). The Human Resource Craze: Human Performance Improvement and Employee Engagement.

Organization Development Journal; Spring 2008: hal. 26.

Gallup. (2004). Study Engaged Employees Inspire Company Innovation. Gallup Management Journal. http://gmj.gallup.com/content/24880/ Gallup-Study-Engaged-EmployeesInspire-Company.aspx [online: akses Desember 2012]

Gallup. (2011). Majority American Worker Not Engaged.

http://www.gallup.com/poll/150383/ majority-american-workers-notengaged-jobs.aspx [online: akses Desember 2012]

Hadi, S. (2000). Metodologi reserach (jilid I-IV). Yogyakarta : Penerbit Andi.

Hallberg, U. E. \& Schaufeli, W. B. 2006. "Same Same" But Different? Can Work Engagement be Discriminated From Job Involvement And Organizational commitment? European Psychologist, 11: hal.119127.

Halsey, G. (2003). Supervising People (terjemahan). Jakarta : Rineka Cipta.
Harter, J. K., Schmidt, F. L., \& Hayes, T. L. (2002). Business-Unitlevel Relationship Between Employee Satisfaction, Employee Engagement, And Business Outcomes: A Meta-Analysis. Journal of Applied Psychology Vol.87: hal.268-79.

Harter, J.K., Schmidt, F., Kilham, E.A. and Asplund, J.W. (2006). Q12 Metaanalysis. The Gallup Organization. http://strengths.gallup.com/private/R esources/Q12MetaAnalysis_Flyer_GEN_08\%2008_BP. pdf [Online: akses September 2012]

Harter, J.K., Schmidt, F., Kilham, E.A., Agarwal, S \& Asplund, J.W. 2010. Causal Impact Of Employee Work Perceptions On The Bottom Line Of Organizations Perspectives on Psychological Science, 5(4): hal. 378-389.

Hasan, S.A \& Subhani, M.I. (2011). Can co-workers motivational efforts pave the way for morale and job commitment for employees?

European Journal of Economics, Finance \&Administrative Sciences, $43 \mathrm{http}: / / m p r a . u b . u n i-$ muenchen.de/35684/1/EJEFAS_Fina 1_coworkers_motivational_efforts_8Dec1 1.pdf (Online: akses Januari 2013)

Hasibuan, M. S.P. (2005). Manajemen Sumber Daya Manusia, Edisi Revisi. Jakarta: Bumi Aksara.

Hewitt Associates LLC. (2004). Employee Engagement. http://www.aon.com/attachments/tho ughtleadership/Trends_Global_Empl 
oyee_E ngagement_Final.pdf

[Online: akses September 2012]

Kahn, W. A. (1990). Psychological

Conditions Of Personal Engagement

And Disengagement At Work.

Academy of management journal

Vol. 33, No. 4: hal. 692-724.

Kasali, Rhenald. (1998). Membidik Pasar

Indonesia: Segmentasi, Targeting,

Positioning. Jakarta : PT.Pustaka

Utama Grafiti.

Kerlinger,F.N. (2003.) Asas-asas

penelitian behavioral (3th ed).

Yogyakarta :Gajah Mada University Press.

Kossen, S. (1993). Aspek Manusia dalam

Organisasi. Jakarta: Erlangga.

Koyuncu, M., Burke, R. J., \& Fiksenbaum,

L. (2006). Work Engagement Among

Women Managers and Professionals

in a Turkish Bank: Potential

Antecedents And Consequences.

Equal Opportunities International,

25: hal. 299-310.

Little, B \& Little, P,.(2006). Employee

Engagement: Conceptual Issues.

Journal of Organizational Culture,

Communications and Conflict,

Volume 10: hal 111 - 118.

Llorens, S., Bakker, A. B., Schaufeli, W., \& Salanova, M. (2006). Testing The Robustness of The Job DemandsResources Model. International Journal of Stress Management Vol. 13: hal. 378-391.

Macey, W.H., Schneider, B., Barbera, K.M \& Young, S.A. (2009). Employee Engagement: Tools for Analysis, Practice, and Competitive Advantage. USA: John Wiley \& Sons.
Macey, W.H \& Schneider, B. (2008). The Meaning of Employee Engagement. Industrial and Organizational Psychology Vol. 1: hal. 3-30.

Marciano, Paul L,. 2010. Carrots and Sticks Don't Work: Build a Culture of Employee Engagement with the Principles of RESPECT. USA: McGraw Hill.

Morris, J.H \& Sherman, J.D. (1981). Generalizability of an Organizational Commitment Model. The Academy of Management Journal Vol. 24, (3): hal.512-526.

Mujiasih, E \& Ratnaningsih, I.Z. (2012). Meningkatkan Work Engagement Melalui Gaya Kepemimpinan Transformasional Dan Budaya Organisasi. http://eprints.unisbank.ac.id/464/1/A RTIKEL-55.pdf [online: akses September 2012]

Nitisemito, A.S. (1996). Manajemen Personalia, Jakarta: Ghalia Indonesia.

Ott, B. (2007).Investors take note: Engagement Boosts Earnings. The Gallup Management Journalhttp://businessjournal.gallup. com/content/27799/investors-takenote-engagement-boostsearnings.aspx?version=print [Online: akses September 2012]

Padmakumar, R., Prabhakar, G.V. (2011). The Role Of Employee Engagement In Work-Related Outcomes. www.idjrb.com/articlepdf/vol1no3e. pdf (akses September 2012)

Rath, Tom. (2011). Gallup: Wellbeing Is The Next Employee Engagement. 
Robinson, D., Perryman, S \& Hayday, S. (2004). The Drivers of Employee Engagement. http://www.wellbeing4business.co.u k/docs/Article\% 20$\%$ 20Engagement\%20research.pdf [Online: akses Agustus 202]

Saks, A.M. (2006). Antecedents And Consequences Of Employee Engagement. Journal of Managerial Psychology Vol. 21 No. 7, 2006.

Sandy, Nusatria \& Suharnomo. (2011). Employee Engagement : Anteseden dan Konsekuensi Studi pada Unit CS PT. Telkom Indonesia Semarang. http://eprints.undip.ac.id/32106/1/Jur nal_Sandi_Nusatria.pdf [Online: akses Januari 2012]

Sastrohadiwiryo, B. S. (2002). Manajemen Tenaga Kerja Idonesia; Administratif \& Operasional. Jakarta: Bumi Aksara

Schaufeli, W. B. \& Bakker, A. B. (2004). Job Demands, Job Resources, And Their Relationship With Burnout And Engagement: A Multi-Sample Study. Journal of Organizational Behavior. Vol. 25: hal. 293.

Schaufeli,W. B., Salanova, M., GonzalezRomá, V., \& Bakker, A. B. (2002). The Measurement Of Engagement And Burnout: A Confirmative Analytic Approach. Journal of Happiness Studies. Vol. 3, Issue 1: hal. 71-92.

Schaufeli,W. B., Bakker, A. B. \& Salanova, M. (2006). The Measurement Of Work Engagement With A Short Questionnaire: A
Cross-National Study. Educational and Psychological Measurement, Volume 66 Number 4: hal. 701-716.

Shadily, H \& Echols, J.M. (1997). Kamus Inggris Indonesia. Jakarta: PT.Gramedia Pustaka.

Shaw, K. (2005). An Engagement Strategy Process For Communicators. Strategic Communication Management. Vol 9, No 3: hal. 2629.

Strauss, G. \& Sayles, LR. (1999). Perilaku Organisasi (Terjemahan Early Sundari). Jakarta: Penerbit Salemba Empat.

Szilagyi, A.D \& Wallace, M.J. ( 1990.) Organizational Behavior and Performance. Glenview, IL: Scott, Foresman.

Tohardi, Ahmad. (2002). Pemahaman Praktis Manajemen Sumber Daya Manusia,. Bandung: Mandar Maju

Tritch, T. (2003). Engagement Drives Results At New Century.Gallup Management Journal http://www.nova.edu/ie/ice/forms/en gagement_drives_results.pdf [online:akses September 2012]

Triton, B.P. (2006). SPSS 13.0 Terapan : Riset Statistik Parametrik. Yogyakarta:Penerbit Andi.

Ubaydillah, A.N. (2006). Mengantisipasi Kelumpuhan Karir. http://www.epsikologi.com/epsi/artikel_detail.asp ?id=195 [online: akses Agustus 2012]

Vazirani, N.A. (2007). Employee Engagement. Working Paper for the SIES College of Management 
Studies, 2007

http://www.siescoms.edu/images/pdf /reserch/working_papers/employee_e ngagement.pdf [online: akses

September 2012]

Wagner, R., \& Harter, J.K. (2006). 12: The Elements of Great Managing. http://kentblumberg.typepad.com/ken t_blumberg/files/12_the_elements_of _great_managing_summarized_by_k ent.pdf [Online: aksesSeptember 2012]

Werther, W.B \& Davis, K. (1989).

Personnel Management And Human

Resources. 2nd ed. New York:

McGraw-Hill .(1993). Human

Resources and Personnel

Management. Fourth Edition. New

York: McGraw-Hill

Winardi, J. (2004). Manajemen Perilaku

Organisasi. Jakarta: Prenada Media.

Yoder, D \& Staudohar, P.D. (1982).

Personnel. Management and

Industrial Relations. New. Jersey:

Prentice-Hall, Inc.

http://www.portalhr.com/people-

management/sisi-lain-engagement/ 